\title{
From workforce intelligence to workforce development: advancing the Eastern Mediterranean pharmaceutical workforce for better health outcomes
}

\author{
Lina Bader ${ }^{1}$, Ian Bates ${ }^{2}$ and Chris John ${ }^{3}$
}

${ }^{1}$ FIP Education, International Pharmaceutical Federation, The Netherlands (Correspondence to: L.R. Bader: lina@fip.org). ${ }^{2}$ School of Pharmacy, University College London, United Kingdom. ${ }^{3}$ Royal Pharmaceutical Society, United Kingdom.

\begin{abstract}
Background: The pharmaceutical workforce in the World Health Organization (WHO) Eastern Mediterranean Region plays a key role in improving health outcomes through responsible use of drugs and optimizing effective choice and use. Investment in this workforce's development and planning is fundamental to achieving universal health coverage.

Aims: To provide an overview of the pharmacy workforce capacity trends in the Region and emphasize the importance of workforce intelligence for strategic development.

Methods: A review of the literature and global pharmacy workforce studies conducted by the International Pharmaceutical Federation to identify trends and issues in the Region.

Results: The Region has high workforce production capacity compared to other WHO regions but challenges in workforce planning and intelligence strategies persist. Effective workforce planning relies not only on quality intelligence, but also on cross-sectoral coordination and stewardship, and the Pharmaceutical Workforce Development Goals provide countries within the Region with a framework for development.
\end{abstract}

Conclusion: There is no workforce development without workforce intelligence.

Keywords: workforce development; workforce intelligence, pharmaceutical workforce, Eastern Mediterranean Region, Pharmaceutical Workforce Development Goals

Citation: Bader LR; Bates I; John C. From workforce intelligence to workforce development: developing the Eastern Mediterranean pharmaceutical workforce for better health outcomes. 2018;24(9):899-904. https://doi.org/10.26719/2018.24.9.899

Received: 04/01/18; accepted: 18/07/18

Copyright $\odot$ World Health Organization (WHO) 2018. Some rights reserved. This work is available under the CC BY-NC-SA 3.0 IGO license (https:// creativecommons.org/licenses/by-nc-sa/3.0/igo)

\section{Introduction}

A report commissioned by the Global Health Workforce Alliance and World Health Organization (WHO) for the 3rd Global Human Resources Forum (Recife, Brazil 2013) states that there is no health without a workforce (1). However, it is equally axiomatic that there is no health workforce without workforce intelligence; effective human resources for health planning are reliant on understanding the state of health workforce quality, accessibility, acceptability and availability at a national level (and increasingly transnational comparisons, particularly in relation to workforce migration and mobility) $(2,3)$. Workforce intelligence provides strategic workforce information to support workforce planning and increased capacity. Strengthening data on human resources for health is a priority for WHO as demonstrated by the recent launch of the National Health Workforce Accounts (4). This links to other objectives focused on policy development and investment in human resources for health aligned with population health needs (5). Other WHO guidelines recommend governance and planning, including national plans to produce and retain graduates in the health workforce informed by needs and intelligence in the labour market (6).

Achieving universal health coverage by 2030, as part of the Sustainable Development Goals (SDGs), depends on access to quality essential health services, and safe and effective use of drugs and vaccines (7). Health workforce, health service delivery and access to essential drugs are three of the six health system building blocks of the WHO (8). The pharmaceutical workforce plays an integral role in bettering health outcomes through optimizing effective choice and responsible use of drugs (9). Pharmaceutical workforce refers to the whole of the pharmacy-related workforce (e.g., registered pharmacist practitioners, pharmaceutical scientists, pharmacy technicians and other pharmacy support workforce cadres, and pre-service students/trainees) working in a diversity of settings (e.g., community, hospital, research and development, industry, military, regulatory and academia) with a diversity of scope of practice. In many countries, pharmacists are the most accessible of all healthcare workers, and as such, are at the forefront of healthcare service delivery (10). Investment in the development of a flexible, adaptable, well-distributed and competent pharmaceutical workforce contributes towards strengthening health systems and achieving universal health coverage and the SDGs. This partly explains why pharmacists have been recognized in the indicator selected by the United Nations (UN) to follow up on the achievement of SDG 3: "Ensure healthy lives 
and promote well-being for all at all ages", specifically target 3.c that focuses on the health workforce (11). In addition to physicians, nursing personnel, midwifery personnel and dentists, the indicator includes the density of pharmacists per population (12).

Health workforce planning in the WHO Eastern Mediterranean Region remains underdeveloped and sufficient evidence to inform health sector reform is lacking. In the low- and middle-income countries of the Region, as in other regions of the world, human resources for health systems typically suffer from poor planning and management, geographic and sectoral distribution imbalances, limited educational and training capacities, workforce shortages and underemployment, and a lack of workforce intelligence required to inform needs-based planning $(13,14)$. As a result of these persistent challenges, researchers have urgently called for the generation of research on the health workforce in the Region (13), and priority areas for research include improving planning and management and the development of minimum databases (14). Despite this, human resources for health literature on health workers in the Region remain scarce, and where literature is retrieved, it is primarily concentrated on the medical and nursing professions $(13,15)$. Markedly less is reported about pharmacy workforce issues in the Region (16).

\section{Global and regional pharmacy workforce trends}

While research into pharmaceutical human resources and pharmacy workforce issues has been garnering more global attention in recent years $(17,18)$, considerably more is published about other health professionals (19). A systematic review of 69 papers published between 1998 and 2008 identified several global trends affecting the pharmacy workforce, including increased feminization and overall distribution imbalances (20). In addition to calling for a "more coordinated monitoring and modelling of the pharmacy workforce worldwide", the review also distinctly found that "there were significant shortfalls of published information regarding the pharmacist workforce in developing nations" compared to more developed countries.

Systematic efforts to address this knowledge gap and build a global evidence base on the pharmacy workforce and its issues are being led by the International Pharmaceutical Federation (FIP). FIP is the global professional leadership body representing $>4$ million pharmacists and pharmaceutical scientists around the world. FIP has collated global pharmaceutical workforce data since 2006, and global reports on the pharmacy workforce were published in 2006, 2009 and 2012, based on survey data collected from 34, 56 and 90 countries and territories, respectively (21-23). The 2006 Global Pharmacy Workforce and Migration Report was the first to highlight issues and trends affecting the pharmacy workforce globally. In this report, a call for action is directed to pharmacy regulators and policy-makers in order to strengthen strategic planning and workforce data systems (21). The 2009 FIP Global Pharmacy Workforce Report strongly recommended that pharmacy workforce planning be integrated into the broader national health workforce planning (22). The 2012 FIP Global Pharmacy Workforce Report stressed the importance of a needsbased approach in the development of a locally relevant workforce plan (23).

Analysis of data from 2006, 2009 and 2012 enabled trends to be monitored over the 2006-2012 period. These 6-year trends are reported in the 2015 FIP report, Global Pharmacy Workforce: Intelligence Trends (24). The report is the first publication of its kind to provide a baseline on the current growing global trend, regarding capacity building and pharmacist numbers. Matching data across the 3 time points provided an overview of mean percentage change in pharmacist capacity (capacity is measured as density: the number of pharmacists per 10000 population). All WHO regions have experienced an increase in the density of pharmacists over the period 2006-2012 (Table 1). Countries in the Eastern Mediterranean Region showed large proportional changes in the pharmacist workforce. The mean pharmacist density in the Region increased markedly by $38.5 \%$ between 2006 and 2012, recording the highest increase after the Western Pacific Region (43.1\%). The analysis was based on 5 countries in the Eastern Mediterranean Region that submitted data to FIP at all data collection points (2006, 2009 and 2012) (24). In terms of rate of increase in the same period, the Eastern Mediterranean displayed the highest proportional change in capacity among all WHO regions.

The relatively high production of pharmacists in the Eastern Mediterranean Region can be partly explained by the regional education capacity. The FIP 2013 Global Education Report analysed global pharmacy-graduate production capacity trends (measured as the mean number of graduates per 10000 population) and found strong correlations between total workforce capacity and the annual graduating cohort $\left(\mathrm{R}^{2}=0.57, \mathrm{P}<0.0001\right)$ (25). Eleven of 22 countries in the Eastern Mediterranean Region were included in the analysis, and results show that the Region exhibited the second highest production capacity in the world, with the Western Pacific Region demonstrating the highest production and the African Region the lowest. The mean number of graduates per 10000 population was 0.46 in the Eastern Mediterranean

\begin{tabular}{lc}
\hline Table 1 Mean change in pharmacist density 2006-2012 \\
$\begin{array}{l}\text { Mean change in pharmacist } \\
\text { density 2006-2012 (\%) }\end{array}$ \\
\hline Africa & 14.8 \\
Eastern Mediterranean & 38.5 \\
Europe & 24.2 \\
Americas & 14.3 \\
South East Asia & 24.1 \\
Western Pacific & 43.1 \\
\hline
\end{tabular}


Region, compared to the total sample mean $(n=109)$ of 0.36. The report also lists Egypt and Jordan among the countries with the highest graduate production capacity in the world, at 1.46 and 1.20 graduates per 10000 population, respectively. While the state of the pharmacy workforce varies among the countries in the Eastern Mediterranean Region (26), an increase in the number of pharmacy schools is well documented, with some schools having a positive impact on practice advancement and playing a significant role in supplying pharmacists to neighbouring countries (27).

\section{Workforce intelligence for workforce development}

FIP has developed a transformative workforce roadmap adopted at the Global Conference on Pharmacy and Pharmaceutical Sciences Education held in Nanjing, China, on 7 and 8 November 2016 (28). The workforce roadmap sets out the desired milestones for education and workforce development of pharmacists and pharmaceutical scientists, clearly linked with a global vision for transforming education for pharmacy and pharmaceutical sciences. The Pharmaceutical Workforce Development Goals (PWDGs) have been developed as a measurable, feasible and tangible means to facilitate action-oriented workforce planning and ways of monitoring progress towards global achievement of the workforce vision (29). They aim to provide a consistent structure for coherent and comprehensive national workforce development actions.

There are 13 PWDGs, gathered into 3 groups: 1) academy: focus on schools, universities and education providers; 2) professional development: focus on the pharmaceutical workforce; and 3) systems: focus on policy development, governmental strategy and planning, and monitoring systems. The PWDGs are aligned with: UN High-Level Commission on Health Employment and Economic Growth Recommendations and Immediate Actions (5); WHO Global Strategy on Human Resources for Health Objectives, Milestones and Policy Options (2); and International Labour Organization, Organization for Economic Co-operation and Development and WHO FiveYear Action Plan for Health Employment and Inclusive Economic Growth (2017-2021) (30).

Workforce intelligence is one of FIP's transformative global PWDGs. PWDG 12 Workforce Intelligence states that all countries and territories should have a national strategy and corresponding actions to collate and share workforce data and workforce planning activities (skill mix, advanced and specialist practice, and capacity). The development of national monitoring systems can identify workforce trends, which in turn enables decision making on deployment and supply of pharmaceutical workforce. Ideally, this should be linked with stewardship and leadership for professional leadership bodies. Country case studies demonstrate that leadership bodies play a significant role in progressing workforce intelligence strategies that are aligned with national and global health workforce tracer indicators (31).

Recent research on the pharmacy workforce in the Eastern Mediterranean Region reported a disconnect between the education, regulation and practice sectors, as well as insufficient engagement of professional organizations and leadership bodies (27,32). A recent in-depth study on Jordan found local deficiencies in workforce planning and intelligence that are linked to both suboptimal levels of cross-stakeholder engagement and the lack of national workforce planning strategies - especially important during a witnessed surge in the number of pharmacy schools (32). The lack of health workforce planning strategies in a climate of increased production and capacity may have serious implications on the utilization of a health workforce within national health systems. In the case of pharmacy in the Region, the increased production of pharmacists without adequate workforce planning strategies, coupled with the lack of effective regulation and clear role descriptions in affecting both private and public sectors, should raise the concern of policy-makers.

Using workforce intelligence to develop strategic workforce strategies relies on purposeful planning that is linked with labour market needs and dynamics, as well as the production capacity and infrastructure to educate and train. The FIP PWDG on workforce intelligence therefore links closely to other goals such as PWDG 1: Academic Capacity (to support supply-side workforce development agendas); PWDG 13: Workforce Policy Formation (strategies to implement needs-based workforce development) and PWDG 11: Workforce Impact (evidence of the impact of the workforce on patient outcomes).

\section{Conclusion}

Using evidence generated from this work, countries and territories in the Eastern Mediterranean Region can identify policy gaps and prioritize the development of workforce planning strategies. They can also learn from other country case studies and adopt approaches and methods based on their needs. It is important to assess trends in the pharmacist workforce against national populations, disease burdens and economic situations. The global pharmaceutical workforce will continue to be monitored and assessed in order to shape workforce development and capacity, thereby realizing the PWDGs. Further work is also needed to develop professional, economic and disease indicators to describe the impact of the pharmaceutical workforce, mainly (though not exclusively) following investment of resources by national economies. Without workforce intelligence data there can be no strategic workforce development.

Funding: None.

Competing interests: None declared. 


\section{De l'information sur les personnels au développement des personnels : faire progresser les personnels œuvrant dans le secteur pharmaceutique en Méditerranée orientale pour de meilleurs résultats sanitaires}

\section{Résumé}

Contexte: L'utilisation responsable des médicaments et l'optimisation de l'efficacité au niveau des choix et de l'utilisation font des personnels œuvrant dans le domaine pharmaceutique dans la Région de la Méditerranée orientale des facteurs clé dans l'amélioration des résultats sanitaires. C'est pourquoi, il est fondamental d'investir dans le développement et la planification de ces personnels si l'on veut réaliser la couverture sanitaire universelle.

Objectifs : Donner un aperçu des tendances au regard des capacités des personnels œuvrant dans le secteur pharmaceutique dans la Région de Méditerranée orientale et mettre l'accent sur l'importance des informations concernant les personnels en vue d'un développement stratégique.

Méthodes : Une analyse de la littérature et des études mondiales sur les personnels du secteur pharmaceutique a été menée par la Fédération internationale du secteur pharmaceutique afin d'identifier les tendances et les enjeux dans la Région de Méditerranée orientale.

Résultats : La Région de la Méditerranée orientale a de fortes capacités de production de personnels par rapport à d'autres Régions de l'OMS, mais des problèmes concernant les stratégies de planification de ces personnels et d'information à leur égard persistent. Une planification efficace des personnels ne dépend pas seulement de la qualité des informations. Elle exige également une coordination et une gestion intersectorielles, et les objectifs de développement pour les personnels de santé fournissent un cadre de développement pour les pays de la Région.

Conclusion : On ne saurait parler de développement des personnels si l'on ne dispose pas d'informations à ce sujet.

من تجميع المعلومات حول القوى العاملة إلى تطويرها: تحسين القوى العاملة الصيدلانية في إقليم شرق المتوسط من

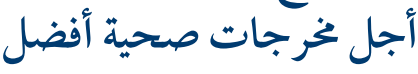
لينة بدر، إيان بيتس، كريس جون

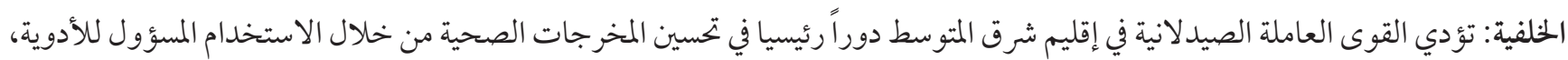

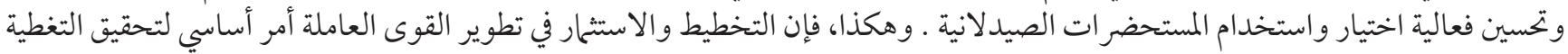
الصحة الشاملة.

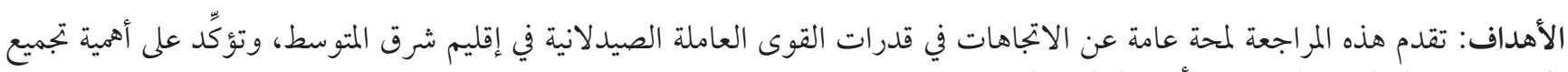

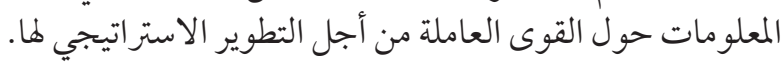

طرق البحث: أجرت الاتحادات الدولية للعاملين الصيدلانيين مراجعة للمنشورات وللدراسات حول القوى العاملة الصيدلانية في العالم لتحديد

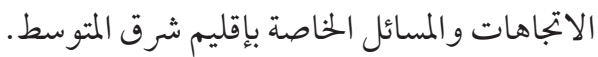

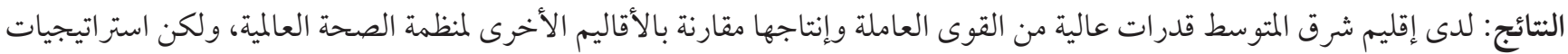

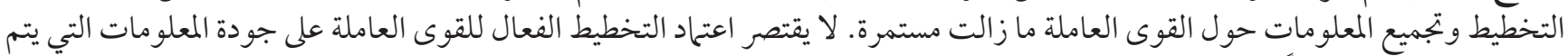

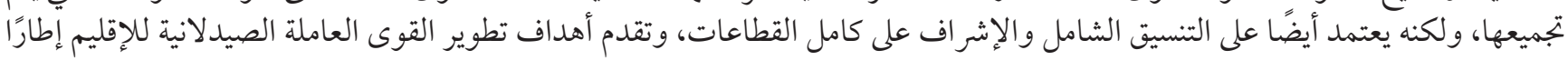
للتطوير الاستنتاجات: ليس هناك تطوير للقوى العاملة دون تجميع المعلو مات حوها.

\section{References}

1. Campbell J, Dussault G, Buchan J, Pozo-Martin F, Guerra Arias M, Leone C, et al. A universal truth: no health without a workforce. Forum Report, Third Global Forum on Human Resources for Health, Recife, Brazil. Geneva, Global Health Workforce Alliance and World Health Organization, 2013 (http://www.who.int/workforcealliance/knowledge/resources/GHWA-a_universal_truth_report.pdf?ua=1 accessed 08 August 2018).

2. Global strategy on human resources for health: Workforce 2030. Geneva: World Health Organization; 2016 (http://www.who.int/ hrh/resources/pub_globstrathrh-2030/en/, accessed 26 July 2018)

3. Siyam A, Dal Poz MR, editors. Migration of health workers: the WHO code of practice and the global economic crisis. Geneva: World Health Organization; 2014 (http://www.who.int/hrh/migration/migration_book/en/, accessed 26 July 2018). 
4. National health workforce accounts: a handbook. Geneva: World Health Organization; 2017 (http://www.who.int/hrh/documents/ brief_nhwa_handbook/en/, accessed 26 July 2018).

5. Final report of the expert group to the High-Level Commission on Health Employment and Economic Growth. Geneva: World Health Organization; 2016 (http://www.who.int/hrh/com-heeg/reports/report-expert-group/en/, accessed 26 July 2018).

6. Transforming and scaling up health professionals' education and training. World Health Organization Guidelines 2013. Geneva: World Health Organization; 2013 (http://apps.who.int/iris/bitstream/10665/93635/1/9789241506502_eng.pdf?ua=1, accessed 26 July 2018).

7. World Health Organization, International Bank for Reconstruction and Development / The World Bank. Tracking universal health coverage: 2017 global monitoring report. Geneva:WHO; 2017 (http://www.who.int/healthinfo/universal_health_coverage/ report/2017/en/, accessed 26 July 2018).

8. Monitoring the building blocks of health systems: a handbook of indicators and their measurement strategies. Geneva: World Health Organization; 2010 (http://www.who.int/healthinfo/systems/WHO_MBHSS_2010_full_web.pdf?ua=1, accessed 26 July 2018).

9. Nkansah N, Mostovetsky O, Yu C, Chheng T, Beney J, Bond CM, et al. Effect of outpatient pharmacists' non-dispensing roles on patient outcomes and prescribing patterns. Cochrane Database Syst Rev. 2010 Jul 7; (7):CDooo336. https://doi. org/10.1002/14651858.CDoo0336.pub2 PMID:20614422

10. Anderson C, Bates I, Futter B, Gal D, Rouse M, Whitmarsh S. Global perspectives of pharmacy education and practice. World Med Health Policy. 2010;2(1):5-18. https://doi.org/10.2202/1948-4682.1052

11. United Nations (UN). Sustainable Development Goals. 2015. (https://www.un.org/sustainabledevelopment/sustainable-development-goals/, accessed 31 December 2017).

12. United Nations (UN). Sustainable Development Goals. SDG Indicators Metadata repository [website] United Nations; 2018 (http://unstats.un.org/sdgs/metadata/, accessed 26 July 2018).

13. El-Jardali F, Jamal D, Abdallah A, Kassak K. Human resources for health planning and management in the Eastern Mediterranean region: facts, gaps and forward thinking for research and policy. Hum Resour Health. 2007 Mar 23;5(9):9. https://doi. org/10.1186/1478-4491-5-9 PMID:17381837

14. El-Jardali F, Makhoul J, Jamal D, Ranson MK, Kronfol NM, Tchaghchagian V. Eliciting policymakers' and stakeholders' opinions to help shape health system research priorities in the Middle East and North Africa region. Health Policy Plan. 2010 Jan;25(1):1527. https://doi.org/10.1093/heapol/czpo59 PMID:19948770

15. El-Jardali F, Dimassi H, Dumit N, Jamal D, Mouro G. A national cross-sectional study on nurses' intent to leave and job satisfaction in Lebanon: implications for policy and practice. BMC Nurs. 2009 Mar 12;8(3):3. https://doi.org/10.1186/1472-6955-8-3 PMID:19284613

16. Hasan S, Sulieman H, Chapman C, Stewart K, Kong DC. Community pharmacy in the United Arab Emirates: characteristics and workforce issues. Int J Pharm Pract. 2011 Dec;19(6):392-9. https://doi.org/10.1111/j.2042-7174.2011.00134.x PMID:22060234

17. Desselle SP. Much needed attention devoted to pharmacy workforce issues. Res Social Adm Pharm. 2006 Sep;2(3):294-8. https:// doi.org/10.1016/j.sapharm.2006.08.003 PMID:17138515

18. Wertheimer AI. Pharmacist manpower planning: whose responsibility is it? Int J Pharm Pract. 2014 Oct;22(5):305-6. https://doi. org/10.1111/ijpp.12117 PMID:25175014

19. Schafheutle EI, Hassell K. Internationally trained pharmacists in Great Britain: what do registration data tell us about their recruitment? Hum Resour Health. 2009 Jun 25;7(51):51. https://doi.org/10.1186/1478-4491-7-51 PMID:19555489

20. Hawthorne N, Anderson C. The global pharmacy workforce: a systematic review of the literature. Hum Resour Health. 2009 Jun 19;7(48):48. https://doi.org/10.1186/1478-4491-7-48 PMID:19545377

21. Chan XH, Wuliji T. Global pharmacy workforce and migration report: a call for action. The Hague: International Pharmaceutical Federation; 2006 (http://www.fip.org/files/fip/publications/PharmacyWorkforceMigration.pdf, accessed 26 July 2018).

22. Wuliji T, editor. 2009 FIP global pharmacy: workforce report. The Hague: International Pharmaceutical Federation; 2009. (http:// www.fip.org/files/fip/publications/2009_FIP_Global_Pharmacy_Workforce_Report.pdf, accessed 26 July 2018).

23. Gal D, Bates I, editors. 2012 FIP global pharmacy: workforce report. The Hague: International Pharmaceutical Federation; 2012 (http://www.fip.org/files/members/library/FIP_workforce_Report_2012.pdf, accessed 26 July 2018).

24. John C, Bates I. Global pharmacy workforce intelligence: trends report 2015. The Hague: International Pharmaceutical Federation; 2015 (https://www.fip.org/files/fip/PharmacyEducation/Trends/FIPEd_Trends_report_2015_web_v3.pdf, accessed 26 July 2018).

25. Bruno A, Bates I. 2013 FIPEd global education report. The Hague: International Pharmaceutical Federation; 2013 (https://fip.org/ files/fip/FIPEd_Global_Education_Report_2013.pdf, accessed 26 July 2018).

26. Kheir N, Zaidan M, Younes H, El Hajj M, Wilbur K, Jewesson PJ. Pharmacy education and practice in 13 Middle Eastern countries. Am J Pharm Educ. 2008 Dec 15;72(6):133. https://doi.org/10.5688/aj7206133 PMID:19325953

27. Bajis D, Moles R, Chaar B. Stakeholders' perspective on quality assurance in the Eastern Mediterranean Region. Am J Pharm Educ. Posted online 26 October 2017 (https://www.ajpe.org/doi/pdf/10.5688/ajpe6482, accessed 26 July 2018). 
28. Bader LR, Bates I, Schneider P, Charman WN. Transforming pharmacy and pharmaceutical sciences education in the context of workforce development. The Hague: International Pharmaceutical Federation; 2017 (http://fip.org/files/fip/publications/FIPEd_ Nanjing_Report_2017_11.10.17.pdf, accessed 26 July 2018).

29. Pharmaceutical workforce development goals. The Hague: International Pharmaceutical Federation; 2016 (http://www.fip.org/ files/fip/PharmacyEducation/Global_Conference_docs/WDGs_online_version.pdf, accessed 26 July 2018).

30. World Health Organization (WHO). "Working for health": a five-year action plan for health employment and inclusive economic growth (2017-21). Geneva: WHO; 2017 (http://who.int/hrh/com-heeg/action-plan-annexes/en/, accessed 10 August 2018).

31. Bader LR, Bates I, editors. Research, development and evaluation strategies for pharmaceutical education and the workforce: a global report. The Hague: International Pharmaceutical Federation; 2017 (http://fip.org/files/fip/publications/FIPEd_RDES.pdf, accessed 26 July 2018).

32. Bader LR, McGrath S, Rouse MJ, Anderson C. A conceptual framework toward identifying and analyzing challenges to the advancement of pharmacy. Res. in Social Adm Pharm. 2017 Mar-Apr;13(2):321-31. https://doi.org/10.1016/j.sapharm.2016.03.001 PMID:27117185 